\title{
Effect of Demographic Factors on Quality of Life in Children with ADHD under Atomoxetine Treatment: 1-Year Follow-up
}

\author{
Moustafa M. Ragab ${ }^{1}$ Ehab M. Eid ${ }^{2}$ Nahla H. Badr ${ }^{2}$ \\ 1 Public Health Department, Institute of Environmental Studies and \\ Researches, Ain Shams University, Cairo, Egypt \\ 2 Public Health Department, Faculty of Postgraduate Childhood \\ Studies, Ain Shams University, Cairo, Egypt \\ ${ }^{3}$ Department of Environmental Medical Sciences, Ain Shams \\ University, Cairo, Egypt \\ J Child Sci 2020;10:e163-e168.
}

\begin{abstract}
Address for correspondence Nahla H. Badr, MSc, Department of Environmental Medical Sciences, Ain Shams University, Cairo 11865, Egypt (e-mail:nhmmb_badr@yahoo.com).
\end{abstract}

\begin{abstract}
Keywords

- attention deficit hyperactivity disorder

- quality of life

- seasonal variation

Attention-deficit hyperactivity disorder (ADHD) is the most common psychiatric disorder in children and adolescents. Symptoms of ADHD and its treatment can impact an individual's quality of life (QoL). The present study aimed to evaluate the effect of atomoxetine treatment, demographic characteristics, and seasonal variation on QoL in children with a recent diagnosis of ADHD and their parents. The present study included a cohort of 200 children diagnosed with ADHD. In addition to the recruited children, one of their parents was included in the study. ADHD symptoms were assessed using Conners' Parent Rating Scale. QoL of the participants was assessed with the PedsQL, while parents' QoL was evaluated using the World Health Organization Quality of Life questionnaire (WHOQOL-Bref). There was significant improvement in pediatric and parental QoL after treatment with atomoxetine. Significant factors related to better QoL in the participants included spring season, above average Conner's score, male sex, and rural residence. However, after using multivariate regression analysis, only patients' sex and Conner's score were significant predictors of pediatric QoL at the end of treatment with atomoxetine. Medical treatment significantly improved QoL in children with ADHD and their parents. Level of improvement was affected by patients' sex and ADHD severity.
\end{abstract}

\section{Introduction}

Attention-deficit hyperactivity disorder (ADHD) is the most common psychiatric disorder in children and adolescents. It is characterized by behavioral problems such as attention deficit, hyperactivity and impulsivity. ${ }^{1}$ Assessment should include careful history taking thorough physical examination and psychological evaluation. Stimulant medications are effective for treatment. However, their side effects and potential of misuse and abuse constitute significant concerns. ${ }^{2}$

received

February 27, 2020

accepted

August 20, 2020
DOI https://doi.org/

10.1055/s-0040-1717104. ISSN 2474-5871.
Some demographic characteristics are linked to increased prevalence of ADHD. It is known that ADHD is more common and is characterized by more severe symptoms in males. ${ }^{3}$ It was also suggested that poor socioeconomic status (SES) increases children's risk of ADHD. ${ }^{4}$

In addition, it was found that genetic and environmental factors play a role in the causation and development of ADHD. ${ }^{5}$ A pattern of increasing prevalence of ADHD has been suggested to be partly linked to exposure to environmental pollutants. ${ }^{6}$ Moreover, it was noted that seasonal and
Copyright (c) 2020 Georg Thieme Verlag License terms KG Stuttgart · New York 
e164 Quality of Life in Children with ADHD under Atomoxetine Treatment Ragab et al.

circadian rhythm instabilities can significantly influence ADHD symptoms. ${ }^{7}$

Symptoms of ADHD can negatively impact an individual's health and quality of life (QoL) and impair function in multiple settings. ${ }^{8}$ Furthermore, this disorder creates significant difficulties in education, social performance, and personal relationships. ${ }^{9}$ Factors related to QoL in children with ADHD include gender, ${ }^{10} \mathrm{SES},{ }^{11}$ and type of treatment. ${ }^{12}$

The present study aimed to evaluate the effect of demographic characteristics and seasonal variation on QoL in children with ADHD and their parents.

\section{Patients and Methods}

The present prospective study included a cohort of 200 newly diagnosed, treatment-naive children with combined-type ADHD recruited from the outpatient clinic of Ain Shams University Hospitals. The study protocol was approved by the local ethical committee and the legal guardians of all included children gave informed consent to participate in the study. In addition to the recruited children, one of the child's parents were included in the study.

The children included in the study were 6 to 12 years old and their diagnosis of ADHD was based on Diagnostic and Statistical Manual of Mental Disorders, 5th edition (DSM-5) criteria. Exclusion criteria were associated chronic clinical conditions, such as "diabetes and thyroid abnormalities," or other neurodevelopmental disorders, such as "autism spectrum and seizure disorders," and intake of other medications.

All patients were subjected to careful history taking and thorough clinical examination. SES was assessed using an Egyptian validated scale. The scale comprises various socioeconomic parameters including income, education, housing, etc. ${ }^{13}$ Patients received medical treatment in the form of oral atomoxetine capsules $(0.5 \mathrm{mg} / \mathrm{kg} / \mathrm{day}$ as initial dose increased after a minimum of 3 days to $1.2 \mathrm{mg} / \mathrm{kg} /$ day with a maximum daily dose of $1.4 \mathrm{mg} / \mathrm{kg} /$ day or $100 \mathrm{mg} /$ day). In addition, patients were subjected to cognitive behavioral therapy sessions.

ADHD symptoms were assessed using Conners' Parent Rating Scale short form Arabic version (CPRS-48), ${ }^{14}$ which is a 48-item questionnaire. Each item is evaluated using 4point Likert's scale (from 0 denoting not at all to 3 denoting severely affected). CPRS-48 has seven subscales which are conduct problem (eight items), learning problem (four items), psychosomatic problem (four items), impulsive-hyperactivity (four items), and anxiety (four items), hyperactivity index (10 items), and inattention (eight items). QoL of the studied children was assessed by the Arabic version of PedsQL 4.0 Generic Core Scales (physical, emotional, social, school functioning $)^{15}$ while parents' QoL was evaluated using the Arabic version of WHO QoL-BREF instrument. ${ }^{16}$ Patients were followed-up for a complete calendar year from September 22, 2018 through September 21, 2019. None of the patients studied were lost to follow-up. Patients' QoL was assessed at baseline (i.e., before treatment) and at the end of every season.
Data obtained from the present study were presented as mean \pm standard deviation (SD), median and interquartile range (IQR) or number and percent. Statistical comparisons were achieved using $t$-test, Mann-Whitney $U$-test, one-way analysis of variance (ANOVA), Kruskall-Wallace test, Fisher's exact test or Chi-square test as appropriate. Regression analysis was used to identify predictors of pediatric QoL. A $p$-value less than 0.05 was considered statistically significant.

\section{Results}

The present study included 200 children diagnosed with ADHD. They comprised 123 males (61.5\%) and 77 females (38.5\%) with a median (IQR) age of 9.0 (7.0-10.0) years. Other baseline data of the studied children are shown in - Table 1. Parents included in the study included 73 fathers (36.5\%) and 127 mothers (63.5\%) with a median (IQR) age of 37.0 (33.3-40.0) years. Of note, 14 mothers (7.0\%) and 11 fathers (5.5\%) had psychopathologies. Most children (79.0\%) were delivered by cesarean section and most mothers (96.0\%) were exposed to environmental tobacco smoke. Other parental characteristics are shown in - Table 2.

After 1 year of treatment, the total pediatric QoL score significantly improved in comparison to the pretreatment levels: median (IQR): 65.0 (61.0-69.0) versus 30.0 (27.0-33.0), $p<0.001$. Significant improvement also applied to all individual scales of pediatric QoL scores. Moreover, the total parental QoL score was significantly improved after

Table 1 Basic data of the studied children $(n=200)$

\begin{tabular}{|c|c|}
\hline \multicolumn{2}{|l|}{ Age (y) } \\
\hline Median (IQR) & $9.0(7.0-10.0)$ \\
\hline $\begin{array}{l}<\text { Median } \\
n(\%)\end{array}$ & $97(48.5)$ \\
\hline $\begin{array}{l}\geq \text { Median } \\
n(\%)\end{array}$ & 103 (51.5) \\
\hline \multicolumn{2}{|l|}{$\begin{array}{l}\text { Gender } \\
n(\%)\end{array}$} \\
\hline Male & $123(61.5)$ \\
\hline Female & 77 (38.5) \\
\hline \multicolumn{2}{|l|}{$\begin{array}{l}\text { SES } \\
n(\%)\end{array}$} \\
\hline Above average & $37(18.5)$ \\
\hline Average & $147(73.5)$ \\
\hline Below average & $16(8.0)$ \\
\hline \multicolumn{2}{|c|}{$\begin{array}{l}\text { Conners' Parent Rating Scale score } \\
n(\%)\end{array}$} \\
\hline Above average & 105 (52.5\%) \\
\hline Average & $88(44.0 \%)$ \\
\hline Below average & 7 (3.5\%) \\
\hline
\end{tabular}

Abbreviations: IQR, interquartile range; SES, socioeconomic status. Note: Data presented as median and IQR or number and percent. 
Table 2 Basic data of the studied parents $(n=200)$

\begin{tabular}{|c|c|}
\hline \multicolumn{2}{|l|}{ Age $(y)$} \\
\hline Median (IQR) & $37.0(33.3-40.0)$ \\
\hline$<$ Median & $102(51.0)$ \\
\hline$\geq$ Median & $98(49.0)$ \\
\hline \multicolumn{2}{|l|}{$\begin{array}{l}\text { Sex } \\
n(\%)\end{array}$} \\
\hline Male & $73(36.5)$ \\
\hline Female & $127(63.5)$ \\
\hline \multicolumn{2}{|l|}{$\begin{array}{l}\text { Work } \\
n(\%)\end{array}$} \\
\hline Working & $173(86.5)$ \\
\hline Homemaker & $27(13.5)$ \\
\hline \multicolumn{2}{|l|}{$\begin{array}{l}\text { Residence } \\
n(\%)\end{array}$} \\
\hline Urban & $126(63.0)$ \\
\hline Rural & $74(37.0)$ \\
\hline \multicolumn{2}{|l|}{$\begin{array}{l}\text { Education } \\
n(\%)\end{array}$} \\
\hline Postgraduate & $5(2.5)$ \\
\hline Graduate & $181(90.5)$ \\
\hline Elementary & $14(7.0)$ \\
\hline Married & $175(87.5)$ \\
\hline Divorced & $25(12.5)$ \\
\hline $\begin{array}{l}\text { Consanguinity } \\
n(\%)\end{array}$ & $17(8.5)$ \\
\hline $\begin{array}{l}\text { Maternal psychopathology } \\
n(\%)\end{array}$ & $14(7.0)$ \\
\hline $\begin{array}{l}\text { IVF } \\
n(\%)\end{array}$ & $6(3.0)$ \\
\hline $\begin{array}{l}\text { Environmental tobacco smoke } \\
n(\%)\end{array}$ & $192(96.0)$ \\
\hline $\begin{array}{l}\text { Acetaminophen during pregnancy } \\
n(\%)\end{array}$ & $174(87.0)$ \\
\hline $\begin{array}{l}\text { Alcoholism during pregnancy } \\
n(\%)\end{array}$ & $6(3.0)$ \\
\hline $\begin{array}{l}\text { Antihypertensives during pregnancy } \\
n(\%)\end{array}$ & $8(4.0)$ \\
\hline $\begin{array}{l}\text { Diabetes during pregnancy } \\
n(\%)\end{array}$ & $13(6.5)$ \\
\hline \multicolumn{2}{|l|}{$\begin{array}{l}\text { Labor } \\
n(\%)\end{array}$} \\
\hline Cesarean section & $158(79.0)$ \\
\hline Vaginal & $42(21.0)$ \\
\hline $\begin{array}{l}\text { Preterm labor } \\
n(\%)\end{array}$ & $15(7.5)$ \\
\hline $\begin{array}{l}\text { Preeclampsia } \\
n(\%)\end{array}$ & $4(2.0)$ \\
\hline
\end{tabular}

Abbreviations: IQR, interquartile range; IVF, in vitro fertilization. Note: Data presented as median and IQR or number and percent. treatment: median (IQR): $87.0(80.0-92.0)$ versus 71.0 (65.0-80.0), $p<0.001$. Likewise, the individual domains were significantly improved ( $\mathbf{-}$ Table $\mathbf{3}$ ).

- Table 4 illustrates the association between pediatric QoL and demographic and clinical data. There was significant association between improved total pediatric QoL scores after treatment and spring season, above average Conners' score of ADHD, male sex of patients, and rural residence. On multivariate regression analysis, significant predictors of QoL included patients sex (odds ratio $[\mathrm{OR}]=-5.1,95 \%$ confidence interval $[\mathrm{CI}]$ : -6.2 to $-4.0, p<0.001)$ and Conners' score $(\mathrm{OR}=-2.1,95 \% \mathrm{CI}:-3.0$ to -1.1 , $p<0.001 ;$ - Table 5).

\section{Discussion}

The current study revealed significant improvement of pediatric QoL and its individual domains after treatment with atomoxetine. These results are consistent with multiple previous studies. In the study of Haynes et $\mathrm{al}^{17}$ on approximately 700 children with ADHD, atomoxetine treatment was associated with improved QoL over 2 years. In another study, it was found that atomoxetine withdrawal resulted in significant deterioration of QoL parallel to the changes in ADHD symptoms. ${ }^{18}$ In addition, it was found that parents of the studied children experienced significant improvement of their QoL; a finding that accords with the conclusions of Escobar et al $^{19}$ who noted that the positive impact of atomoxetine on children QoL was associated with a corresponding positive influence on their parents.

In the present study, it was found that the spring season has the most significant impact on patients' QoL. The improved QoL in spring may be related to improved sun exposure and increased vitamin D levels. This explanation may be supported by findings of other reports. In one recent study, vitamin-D deficiency was associated with ADHD symptoms in children. ${ }^{20}$ One recent meta-analysis confirmed these conclusions. ${ }^{21}$

Of note, the study of Wynchank et $\mathrm{al}^{7}$ found that worsening of ADHD symptoms in autumn and/or winter may be attributed the association between ADHD and seasonal affective disorder (SAD) commonly seen in adult patients with ADHD. However, the prevalence of SAD is much lower in children as compared with adults. ${ }^{22}$ Moreover, children with SAD were excluded from the present study.

In this study, it was found that the children with below average Conners' score had significantly lower QoL. The association between ADHD symptoms severity and QoL was reported by the study of Mulraney et $\mathrm{al}^{23}$ on 392 children with ADHD assessed at three time points $(0,6$, and 12 months). The study found that parent-reported ADHD symptoms predicted poor QoL at each subsequent time point.

Assessment of the relation between children QoL and various demographic data revealed significantly all-year and seasonal lower QoL in female children after treatment. In harmony with these results, the study of Dallos et $\mathrm{al}^{24}$ on 
e166 Quality of Life in Children with ADHD under Atomoxetine Treatment Ragab et al.

Table 3 Pediatric and parental quality of life before and after treatment

\begin{tabular}{|c|c|c|c|}
\hline & Before treatment & After treatment & p-Value \\
\hline \multicolumn{4}{|l|}{ Pediatric QoL } \\
\hline Total QoL score & $30.0(27.0-33.0)$ & $65.0(61.0-69.0)$ & $<0.001$ \\
\hline Psychosocial scale & $31.0(24.0-42.0)$ & $55.0(48.0-62.0)$ & $<0.001$ \\
\hline Physical functioning scale & $38.0(33.0-40.0)$ & $76.5(72.0-81.0)$ & $<0.001$ \\
\hline Emotional function scale & $24.0(16.0-32.0)$ & $60.0(50.0-65.0)$ & $<0.001$ \\
\hline Social function scale & $24.0(20.0-28.0)$ & $55.0(45.0-65.0)$ & $<0.001$ \\
\hline School function scale & $22.0(20.0-31.0)$ & $55.0(40.0-65.0)$ & $<0.001$ \\
\hline \multicolumn{4}{|l|}{ Parental QoL } \\
\hline Total QoL score & $71.0(65.0-80.0)$ & $87.0(80.0-92.0)$ & $<0.001$ \\
\hline Parental physical health domain & $69.0(63.0-80.0)$ & $86.0(71.0-91.0)$ & $<0.001$ \\
\hline Parental psychological health domain & $73.0(67.0-80.0)$ & $87.0(80.0-93.0)$ & $<0.001$ \\
\hline Parental social relationship domain & $73.0(67.0-80.0)$ & $87.0(73.0-93.0)$ & $<0.001$ \\
\hline Parental environment domain & $73.0(63.0-80.0)$ & $88.0(83.0-93.0)$ & $<0.001$ \\
\hline
\end{tabular}

Abbreviation: QoL, quality of life.

Note: Data presented as median and interquartile range (interquartile range).

Table 4 Relation between pediatric quality of life and demographic and clinical data

\begin{tabular}{|c|c|c|}
\hline & Pediatric QoL & p-Value \\
\hline \multicolumn{3}{|c|}{ Season of assessment } \\
\hline Spring & $64.0(61.0-67.8)$ & \multirow[t]{4}{*}{$<0.001$} \\
\hline Summer & $60.0(55.0-64.0)$ & \\
\hline Autumn & $62.0(59.3-66.0)$ & \\
\hline Winter & $60.0(55.0-64.0)$ & \\
\hline \multicolumn{3}{|c|}{ Conner's Parent Rating Scale score } \\
\hline Above average & $63.0(59.0-67.0)$ & \multirow[t]{3}{*}{$<0.001$} \\
\hline Average & $60.0(58.0-64.0)$ & \\
\hline Below average & $54.0(53.0-57.0)$ & \\
\hline \multicolumn{3}{|l|}{ Patients' age } \\
\hline$<$ Median & $62(59.0-65.0)$ & \multirow[t]{2}{*}{0.12} \\
\hline$\geq$ Median & $64.0(61.0-67.0)$ & \\
\hline \multicolumn{3}{|l|}{ Patients' sex } \\
\hline Male & $64.0(61.0-66.0)$ & \multirow[t]{2}{*}{$<0.001$} \\
\hline Female & $58.0(56.0-60.0)$ & \\
\hline \multicolumn{3}{|l|}{ Patients' SES } \\
\hline Above average & $61.0(57.0-65.5)$ & \multirow[t]{3}{*}{0.93} \\
\hline Average & $61.0(59.0-65.0)$ & \\
\hline Below average & $63.5 .0(57.25-65.0)$ & \\
\hline \multicolumn{3}{|l|}{ Parental age } \\
\hline$<$ Median & $60.0(58.0-65.0)$ & \multirow[t]{2}{*}{0.15} \\
\hline$\geq$ Median & $62.0(59.0-65.0)$ & \\
\hline \multicolumn{3}{|l|}{ Parental sex } \\
\hline Male & $64.0(61.0-65.5)$ & $<0.001$ \\
\hline
\end{tabular}

Table 4 (Continued)

\begin{tabular}{|c|c|c|}
\hline & Pediatric QoL & $p$-Value \\
\hline Female & $60.0) 57.0-65.0($ & \\
\hline \multicolumn{3}{|l|}{ Parental work } \\
\hline Working & $61.5 .0(58.0-65.0)$ & \multirow[t]{2}{*}{0.36} \\
\hline Housewife & $60.0(59.0-64.0)$ & \\
\hline \multicolumn{3}{|l|}{ Residence } \\
\hline Urban & $60.5(57.75-65.0)$ & \multirow[t]{2}{*}{0.028} \\
\hline Rural & $63.0(59.75-65.0)$ & \\
\hline \multicolumn{3}{|c|}{ Parental education } \\
\hline Postgraduate & $66.0(64.0-67.5)$ & \multirow[t]{3}{*}{0.09} \\
\hline Graduate & $61.0(58.0-65.0)$ & \\
\hline Elementary & $60.5) 58.0-63.0($ & \\
\hline \multicolumn{3}{|l|}{ Marital status } \\
\hline Married & $61.0(59.0-65.0)$ & \multirow[t]{2}{*}{0.073} \\
\hline Divorced & $60.0(56.5-64.5)$ & \\
\hline
\end{tabular}

Abbreviations: SES, QoL, quality of life; socioeconomic status.

Note: Data presented as median and interquartile range (interquartile range).

178 children with ADHD found that lower self-reported QoL was associated with female gender. This may be related to the less severe form of ADHD symptoms in males probably due to the protective effects of testosterone. ${ }^{25}$

In addition, the present study found significantly higher QoL after treatment in children living in rural areas. This finding may be surprising in respect to the lower rate of utilization of ADHD medications in rural areas. ${ }^{26,27}$ However, the better QoL in children with ADHD living in rural areas may be related to lower pollution rates. ${ }^{28,29}$ 
Table 5 Regression analysis for predictors of pediatric QoL after 1 year

\begin{tabular}{|c|c|c|c|c|}
\hline & \multicolumn{2}{|l|}{ Univariate analysis } & \multicolumn{2}{|l|}{ Multivariate analysis } \\
\hline & OR (95\% Cl) & $p$-Value & OR $(95 \% \mathrm{Cl})$ & $p$-Value \\
\hline Age & $0.34(-0.03$ to 708.0$)$ & 0.074 & $0.23(-0.06$ to 0.52$)$ & 0.13 \\
\hline Sex & $-5.6(-6.8$ to -4.5$)$ & $<0.001$ & $-5.1(-6.2$ to -4.0$)$ & $<0.001$ \\
\hline Conners' Parent Rating Scale score & $-3.0(-4.1$ to -1.9$)$ & $<0.001$ & $-2.1(-3.0$ to -1.1$)$ & $<0.001$ \\
\hline Residence & $1.6(0.24$ to 2.99$)$ & 0.021 & $0.96(-0.13$ to 2.1$)$ & 0.084 \\
\hline
\end{tabular}

Abbreviations: $\mathrm{Cl}$, confidence interval; OR, odds ratio; QoL, quality of life.

\section{Limitations}

Results of the present study are limited by the lack of comparison between children with ADHD under atomoxetine and those under other types of pharmacological and nonpharmacological treatment.

\section{Conclusion}

In conclusion, we revealed significant improvement of QoL in children with ADHD and their parents. Improvement is more pronounced in the spring, in male patients, and in patients with less severe ADHD symptoms.

\section{Funding \\ None. \\ Conflict of Interest \\ None declared.}

\section{References}

1 Huang X, Wang M, Zhang Q, Chen X, Wu J. The role of glutamate receptors in attention-deficit/hyperactivity disorder: From physiology to disease. Am J Med Genet B Neuropsychiatr Genet 2019; 180(04):272-286

2 Ciocca M. Attention deficit hyperactivity disorder in athletes. Clin Sports Med 2019;38(04):545-554

3 Arnett AB, Pennington BF, Willcutt EG, DeFries JC, Olson RK. Sex differences in ADHD symptom severity. J Child Psychol Psychiatry 2015;56(06):632-639

4 Keilow M, Wu C, Obel C. Cumulative social disadvantage and risk of attention deficit hyperactivity disorder: Results from a nationwide cohort study. SSM Popul Health 2020;10:100548

5 Dam SA, Mostert JC, Szopinska-Tokov JW, Bloemendaal M, Amato $\mathrm{M}$, Arias-Vasquez A. The role of the gut-brain axis in attention-deficit/hyperactivity disorder. Gastroenterol Clin North Am 2019; 48(03):407-431

6 Myhre O, Låg M, Villanger GD, et al. Early life exposure to air pollution particulate matter ( $\mathrm{PM}$ ) as risk factor for attention deficit/hyperactivity disorder (ADHD): Need for novel strategies for mechanisms and causalities. Toxicol Appl Pharmacol 2018; 354:196-214

7 Wynchank DS, Bijlenga D, Lamers F, et al. ADHD, circadian rhythms and seasonality. J Psychiatr Res 2016;81:87-94

8 Caballero J, Darsey EH, Walters F, Belden HW. Methylphenidate extended-release oral suspension for the treatment of attention-deficit/hyperactivity disorder: a practical guide for pharmacists. Integr Pharm Res Pract 2017;6:163-171

9 Bashiri A, Ghazisaeedi M, Shahmoradi L. The opportunities of virtual reality in the rehabilitation of children with attention deficit hyperactivity disorder: a literature review. Korean J Pediatr 2017;60(11):337-343

10 Klassen AF, Miller A, Fine S. Health-related quality of life in children and adolescents who have a diagnosis of attention-deficit/hyperactivity disorder. Pediatrics 2004;114(05):e541-e547

11 Xiang YT, Luk ES, Lai KY. Quality of life in parents of children with attention-deficit-hyperactivity disorder in Hong Kong. Aust N Z J Psychiatry 2009;43(08):731-738

12 Matthijssen AM, Dietrich A, Bierens M, et al. Effects of discontinuing methylphenidate on strengths and difficulties, quality of life and parenting stress. J Child Adolesc Psychopharmacol 2020;30 (03):159-165

13 El-Shakhs A. Social level and the economic scale of the family: the scale manual. In: Anglo-Egyptian library, Cairo2013. PMID:23780595

14 Shata ZN, Abu-Nazel MW, Fahmy SI, El-Dawaiaty AA. Efficacy of a psychosocial intervention for parents of children with attention deficit hyperactivity disorder, Alexandria, Egypt. J Egypt Public Health Assoc 2014;89(01):9-15

15 Arabiat D, Elliott B, Draper P, Al Jabery M. Cross-cultural validation of the Pediatric Quality of Life Inventory 4.0 (PedsQL) generic core scale into Arabic language. Scand J Caring Sci 2011;25(04): 828-833

16 Ohaeri JU, Awadalla AW. The reliability and validity of the short version of the WHO quality of life instrument in an Arab general population. Ann Saudi Med 2009;29(02):98-104

17 Haynes V, Lopez-Romero P, Anand E. Attention-deficit/hyperactivity disorder Under Treatment Outcomes Research (AUTOR): a European observational study in pediatric subjects. Atten Defic Hyperact Disord 2015;7(04):295-311

18 Thome J, Dittmann RW, Greenhill LL, et al. Predictors of relapse or maintenance of response in pediatric and adult patients with attention-deficit/hyperactivity disorder following discontinuation of long-term treatment with atomoxetine. Atten Defic Hyperact Disord 2017;9(04):219-229

19 Escobar R, Montoya A, Polavieja P, et al. Evaluation of patients' and parents' quality of life in a randomized placebo-controlled atomoxetine study in attention-deficit/hyperactivity disorder. J Child Adolesc Psychopharmacol 2009;19(03):253-263

20 Fasihpour B, Moayeri H, Shariat M, Keihanidoust Z, Effatpanah M, Khedmat L. Vitamin D deficiency in school-age Iranian children with attention-deficit/hyperactivity disorder (ADHD) symptoms: A critical comparison with healthy controls. Child Neuropsychol 2020;26(04):460-474

21 Gan J, Galer P, Ma D, Chen C, Xiong T. The effect of vitamin D supplementation on attention-deficit/hyperactivity disorder: a systematic review and meta-analysis of randomized controlled trials. J Child Adolesc Psychopharmacol 2019;29(09):670-687

22 Swedo SE, Pleeter JD, Richter DM, et al. Rates of seasonal affective disorder in children and adolescents. Am J Psychiatry 1995;152 (07):1016-1019

23 Mulraney M, Giallo R, Sciberras E, Lycett K, Mensah F, Coghill D. ADHD symptoms and quality of life across a 12-month period in children with ADHD: a longitudinal study. J Atten Disord 2017;23 (13):1675-1685 
e168 Quality of Life in Children with ADHD under Atomoxetine Treatment Ragab et al.

24 Dallos G, Miklósi M, Keresztény Á, et al. Self- and parent-rated quality of life of a treatment naïve sample of children with ADHD: the impact of age, gender, type of ADHD, and comorbid psychiatric conditions according to both a categorical and a dimensional approach. J Atten Disord 2017;21(09):721-730

25 Martel MM, Klump K, Nigg JT, Breedlove SM, Sisk CL. Potential hormonal mechanisms of attention-deficit/hyperactivity disorder and major depressive disorder: a new perspective. Horm Behav 2009;55(04):465-479

26 Knopf H, Hölling H, Huss M, Schlack R. Prevalence, determinants and spectrum of attention-deficit hyperactivity disorder (ADHD) medication of children and adolescents in Germany: results of the German Health Interview and Examination Survey (KiGGS). BMJ Open 2012;2(06):e000477
27 Sánchez Martínez DP, Guillén Pérez JJ. [The epidemiology of pharmacologically treated attention deficit hyperactivity disorder (ADHD) in the Region of Murcia, Spain: Differences by gender, age and location of residence] (in Spanish). An Pediatr (Barc) 2018;88(04):183-190

28 Aghaei M, Janjani H, Yousefian F, Jamal A, Yunesian M. Association between ambient gaseous and particulate air pollutants and attention deficit hyperactivity disorder (ADHD) in children; a systematic review. Environ Res 2019;173:135-156

29 Markevych I, Tesch F, Datzmann T, Romanos M, Schmitt J Heinrich J. Outdoor air pollution, greenspace, and incidence of ADHD: a semi-individual study. Sci Total Environ 2018; 642:1362-1368 